\title{
The U.S. Men’s Shaving Cream Market: A Competitive Profile
}

\author{
Y. Datta \\ Northern KY University, Highland Heights, KY 41099, USA
}

\begin{abstract}
Porter identifies high market share with cost leadership strategy which is based on the idea of competing on a price lower than that of the competition. However, in most consumer markets a business should serve the middle class by competing in the mid-price segment, offering quality better than that of the competition at a somewhat higher price. It is this path that can lead to market share leadership: a strategy that can be both profitable and sustainable. The U.S. men's shaving cream market consists of two major product-market segments: gel and foam. We test the hypothesis that the best-selling brand is very likely to be a member of the mid-price segment with a price tag that is higher than that of the nearest competition. This study is based on annual U.S. sales data for 2008 and 2007 from discount retail stores, food stores, and drug stores. We performed two separate analyses for 2008 and 2007, using cluster analysis as the main analytic tool. The results were remarkably consistent between the two years. In the gel segment-by far the most important-the price-quality segmentation analysis supported our hypothesis. An interesting finding is that, for both the gel and foam segments, we found the rank order correlation of brand unit price between 2007 and 2008 as highly significant. This means that in this market management considers the price of a brand as a strategic rather than a tactical variable. Although, technically the results for the foam segment were negative, this does not necessarily contradict our hypothesis. Finally, we discovered six strategic groups in the industry and have tried to articulate what their competitive strategy is.
\end{abstract}

Keywords: an integrated approach to market segmentation, price-quality segmentation, market share leadership, strategic group theory, operationalizing competitive strategy, price a strategic variable

\section{Introduction}

Porter (1980, 1985) associates high market share with cost leadership strategy. Mintzberg (1988) calls this strategy as "price differentiation" because it is based on a price that is lower than that of the competition. However, according to the PIMS research, customer-perceived quality is much more vital to long-term competitive position and profitability than any other variable (Gale, 1992; Buzzell \& Gale, 1987, p. 7). So, a business seeking market share leadership should offer quality that is better than that of the nearest competition (Buzzell, 2004, p. 480; Datta, 2010a, 2010b).

But, how can a business make this idea operational? In most consumer markets the answer lies in catering to the middle class by competing in the mid-price segment (Datta, 2010a, 2010b). This is the socio-economic

Y. Datta, Ph.D., Professor Emeritus, College of Business, Northern KY University.

Correspondence about this article should be sent to Y. Datta, 2311, N. Andrea Pt., Lecanto, FL 34461 (USA). E-mail: datta@nku.edu. 
segment that represents about 40\% of households in America (Datta, 2012). It is also the customer group that Procter \& Gamble (P\&G) - the leading global consumer products company-has successfully served in the past (Lafley \& Charan, 2008, p. 12). But, to become a market share leader a business must also distinguish itself by offering - relative to the nearest competition-a higher customer-perceived quality at a somewhat higher price. This is necessary for two reasons: (1) to maintain an image of quality; and (2) to ensure that the strategy is profitable and sustainable (Datta, 2010a, 2010b).

\section{Close Link Between Quality and Price}

As mentioned above, customer perceived quality is the most important variable contributing to the long-term success of a business. However, quality cannot meaningfully be separated from price (Datta, 1996). Today's global economy offers a bewildering array of brands in many markets with diverse grades of quality at different prices that most consumers find difficult to comprehend. Quality, in general, is a complex, multi-dimensional concept that is often not easy to understand. Also, frequently, unbiased data on quality is not available for many products. So, consumers regularly use relative price as a symbol of quality to form broad images of differences in quality among various brands. Such prior attitudes can play an important role in consumer behavior (Oxenfeldt, 1960; Shapiro, 1968).

Businesses, too, often use price to position themselves within a price-quality segment (Datta, 1996). A well-known example is Motel 6 which has positioned itself in the economy segment of the U.S. motel industry as the brand with a claim of offering "the lowest price of any national chain" (Datta, 2010a).

A factor that plays an important role in competition is brand equity (Datta, 2010b). Hamel and Prahalad (1994, pp. 237, 252) suggest that in today's highly competitive markets it is vital for a business to create a "share of mind" among global customers. They say that what convinces a buyer to purchase a product from "Sony, Canon, or Toyota is less the length of the warranty period than the strength of the quality warrant implicit in the brand" (italics added).

Unfortunately, we could not include quality in our study because data on it was not available for men's shaving cream.

\section{Men’s Shaving Cream Market: History and Technology}

Shaving serves an important need: personal grooming. It is a multi-technology, multi-product industry of which the men's shaving cream is a relatively small part. Personal grooming, along with body care and oral care, constitute the broader market for personal care (for an overview of this market see Datta, 2010b, Fig. 1).

The U.S. men's shaving cream industry has several product-market segments. With a market share of $69 \%$ in 2008, shaving gel was by far the largest segment in this market, followed by foam's $26 \%$, a distant second. So, we have focused on these two segments that account for $95 \%$ of total dollar sales for $2008^{1}$.

At present shaving gels dominate the men's shaving cream market. But before gel "there was foam, and before foam there were creams, and before the creams, there was plain old soap” [along with a brush and a mug] (Pinfold, 1999, p. 130).

\section{First Brushless Shaving Cream}

The first innovation in the shaving cream market was the brushless shaving cream. However, there are conflicting views about which was the first U.S. brand to merit this distinction. Woodward (1939) says that

\footnotetext{
${ }^{1}$ For a citation of the source of data in this study, see footnote 8.
} 
Colgate introduced the first brushless shaving cream, Rapid-Shave, in America in 1914-1915. Nonetheless, according to Burma Shave's chronicler, Rowsome (1965), the British-made Lloyd's Euxesis was the original brushless shaving cream. But, Burma Shave, which was sold in the U.S. from 1925 to 1966, was the first American entry to be successful (Larson \& Sundberg, 2006, p. viii; Rowsome, 1965).

In contrast, Perio-Inc., the present owner of Barbasol, says that this honor goes to Barbasol. According to the company's website, the first brushless shaving cream in the U.S. was invented in 1919 by MIT's Prof. Shields, who called it Barbasol. Soon it was endorsed by such celebrities as Babe Ruth and Knute Rockne in newspaper ads ${ }^{2}$. Laura Ries (2006), a well-known marketing expert, also credits Barbasol for inventing "the 'brushless' shaving cream, a new category and a successful new brand”.

Based on the above evidence, we think Barbasol's claim as the first successful brushless shaving cream seems to have far more merit than the case presented by the backers of Burma Shave.

Interestingly, Burma Shave became very famous for its roadside signs with catchy jingles that first appeared in Minnesota in 1925 (Rowsome, 1965, p. 14).

\section{Aerosol Foam Shaving Cream}

The next major advance in this market was the aerosol can. The aerosol can was first patented by a Norwegian in 1927 (Sviokla \& Paoni, 2005). In the early 1950s Barbasol changed its formulation from a thick cream in a tube to a fluffy foam in an aerosol $\mathrm{can}^{3}$, a practice that was soon followed by others, such as Gillette Foamy in 1953 (Howe, 2005).

\section{First Gel Shaving Cream}

In 1970 S.C. Johnson \& Son entered the personal care market by introducing Edge Gel—the first shaving gel for men for which it was awarded a patent in 1970. This has been the last major innovation in the men's shaving cream industry. In 1966 the company introduced Pledge, the first sprayable furniture polish in an aerosol can. In its quest for entering the men's shaving cream market, the company engineers found that gel was a better skin lubricant than the then-popular foam shaving cream. But then how do you go about dispensing gel from an aerosol can? The company solved this problem by "introducing an expandable bladder in the bottom of the can" (Sviokla \& Paoni, 2005; also see Ries, 2006).

Edge went on to dominate the men's shaving gel market and has become a "mega” brand (Ries, 2006). More importantly, while the market for men's shaving gel has expanded steadily, the demand for shaving foam has relatively become much smaller. This is because, as noted above, gel provides extra lubrication and protection that is preferred by many consumers over the foam shaving cream (Toedt, Koza, \& Cleef-Toedt, 2005, p. 57).

Nonetheless, through in-house research, a major competitor in this business has recently learnt that a segment of foam users are preferring foam over gel not because it is more economical, but because they perceive that foam offers the benefit of "high lather and a clean rinse feel". The company has not yet documented the size of this segment.

In 2008 total retail sales of men's foam shaving cream were $\$ 49$ million, as opposed to $\$ 131$ million for gel shaving cream. Also while 20 brands were competing in the gel segment in 2008, only eleven did so in the foam segment.

\footnotetext{
2 http://www.perio-inc.com/ourstory/history/\#barbasol (Retrieved on June 9, 2011).

${ }^{3}$ http://www.perio-inc.com/ourstory/history/\#barbasol (Retrieved on June 9, 2011).
} 
In 1989 S. C. Johnson \& Son won a lawsuit against Gillette Foamy Gel for violating its gel patent. However, Edge Gel's patent expired in Dec. 1987 (The New York Times, 1989). Thus Edge may have lost its edge because this event opened the door to potential competitors to jump into the shaving gel market (Sloan, 1988). Nevertheless, Edge was a clear front runner in 2008 with a market share (units) of $35.9 \%$ followed by Gillette Series with 22.9\% (see Table 1).

In May 2009 S.C. Johnson sold its shaving gel business to Energizer Holdings, the owner of Schick safety razor and blades (Burke, 2009).

\section{Shaving Cream Technology}

The modern men's shaving preparations are intended to do several things: (1) to lubricate the skin; (2) to enable the cutting blade to cut the protruding hair, but not the surrounding skin; (3) to moisten and soften hair to make it easier to cut them, cushion the effect of the razor, and provide a residual film to soothe the skin; and (4) to prevent skin irritation (Toedt, Koza, \& Cleef-Toedt, 2005, p. 55; Berlow, 1993).

The chemistry of shaving cream. The residual film should be of the proper $\mathrm{pH}$ value: neither overly alkaline nor too acidic; it should correspond to the skin's [normal] pH level (Berlow, 1993).

Soap is an important ingredient of shaving cream. It creates a film on the skin that reduces the resistance a blade encounters as it glides along the outermost layer of the skin (epidermal) without cutting into the deeper vascular (vessels carrying blood) dermal skin layer (Toedt, et al., 2005, p. 55).

A vital function performed by soap is that of a surfactant. A surfactant lowers the surface tension of a liquid, allowing easier spreading, and lowers the interfacial tension between two liquids (Rosen, 2004). A surfactant can loosen, emulsify (disperse in water), and hold soil in suspension (Cole, Browning, \& Schroeder, 2003, p. 63).

A surfactant is an organic compound with a long molecule each end of which has different properties. One end of this molecule, the "tail," is "hydrophobic" ("water hating”), and the other end, the "head," is "hydrophilic" ("water loving”). While the hydrophobic end is attracted to dirt and grease, the hydrophilic side attracts water. Thus the surfactant grabs the dirt and grease and dissolves it in water (Cole, Browning, \& Schroeder, 2003, pp. 63-64; Rosen, 2004).

Shaving creams are typically made out of a mixture of two things. One is a sodium salt-e.g., sodium hydroxide (an alkali) also known as lye or caustic soda—or a potassium salt (e.g., potassium hydroxide). It is then mixed with a fatty acid, e.g., stearic acid, or palmitic acid. Both stearic acid and palmitic acid are saturated fatty acids; stearic acid is derived from tallow (animal fat); palmitic acid generally comes from the oil of palm trees (Toedt, et al., 2005, p. 56).

However, today manufacturers of shaving cream are using triethanolamine instead of (say) sodium hydroxide, to interact with stearic (or palmitic) acid. Triethanolamine is a synthetic organic chemical compound that is caustic (or "base"). We found it listed as an ingredient on the shaving cans of all major brands of shaving cream - both gel and foam. It has several things going for it: (1) Like soap, it is a surfactant, but does a better job (Berlow, 1993); (2) It has a $\mathrm{pH}$ of 5-6 which is similar to skin $\mathrm{pH}$; so, it is able to act as a $\mathrm{pH}$ balancer to neutralize excess acid; and (3) It is an emulsifier that is able to hold oil and water together on the facial skin ${ }^{4}$.

Ingredients of shaving cream. By far the largest component of a shaving cream is water which can be as high as $\mathbf{8 0 \%}$. The next most important are stearic acid (or palmitic acid) and triethanolamine (Berlow, 1993).

$4 \quad$ http://www.cosmeticsdatabase.com/ingredient.php?ingred06=706639;http://en.wikipedia.org/wiki/Triethanolamine; http://en.wikipedia.org/wiki/Triethanolamine (Retrieved on June 9, 2011). 
In addition, there are numerous others that are listed below (Toedt, et al., 2005, p. 56):

a. Skin cleansers and antiseptics (e.g., triclosan, sodium lauryl sulfate);

b. Product thickeners (e.g., acrylate copolymers, cellulose polymer, carrageenan, hydroxyethylcellulose);

c. Lubricants and emollients (e.g., lanolin, allantoin, sorbitol);

d. Hair and skin softeners/hydrating humectants (e.g., propylene glycol, glycerin, PEG compounds);

e. Skin conditioners (e.g., aloe vera gel, sodium cocoyl isothionate, vitamin E acetate, panthenol);

f. Preservatives (e.g., BHT, methylparaben, propylparaben, sodium benzoate);

g. Herbal extracts;

h. Fragrance;

i. $\quad$ Propellants (e.g., isobutane, propane, pentane, butane, isopentane).

An emollient is a substance that softens and soothes the skin. A humectant is a non-oily ingredient that attracts moisture from the atmosphere, retards evaporation, and promotes water retention ${ }^{5}$.

The above ingredients are combined in a three-piece metal can containing propellants that dispense foam or gel to the shaver's skin. Also, the gel shaving creams contain a polymer and other surfactant materials to create a clear gel structure (Toedt, et al., 2005, p. 57).

In comparison with foam shaving creams, shaving gels are more efficient because a smaller amount is necessary for each shave. This is because the user lathers the gel while shaving rather than applying an already lathered cream ${ }^{6}$.

\section{Price-Quality Segmentation Profile: Men’s Shaving Cream Market}

We have employed cluster analysis as the primary statistical tool in this study. As suggested by Ketchen and Shook (1996), we have taken several steps to make this endeavor as objective as possible. First, this study is not ad-hoc, but is grounded in a theoretical framework, as indicated earlier. An important part of this framework is that most consumer markets can potentially be divided in five price-quality segments or groups-from ultra-economy to super-premium. Third, we have relied on two different cluster analysis techniques—KMeans and Hierarchical— to establish the reliability or consistency of clusters. Fourth, we are fortunate that we were able to get annual sales data for our study for two years. Thus, this data has provided a powerful vehicle for subjecting cluster consistency to an additional test. Finally, we have also tried to seek external validity for cluster justification whenever possible. For example, $P \& G$ has clearly recognized several of its brands as premium brands, one of which is Gillette Fusion: a brand that is a part of this study ${ }^{7}$.

This analysis is based on U.S. retail sales data for 2008 and 2007 from food stores (supermarkets) with sales of over \$ 2 million, and drug stores over \$ 1 million; it also includes discount stores, such as Target and K-Mart, but excludes Wal-Mart as well as warehouse clubs, e.g., Sam’s Club, Costco, and BJ's. It also does not include the "dollar" stores, such as Dollar General, Family Dollar, and Dollar Tree .

The data provides total dollar and unit sales, no-promotion dollar and unit sales, and promotion ${ }^{9}$ dollar

\footnotetext{
${ }^{5}$ http://en.mimi.hu/beauty/humectant.html (Retrieved on June 9, 2011).

6 http://www.wisegeek.com/what-is-shaving-gel.htm (Retrieved from June 9, 2011).

7 http://www.pg.com/en_US/investors/financial_reporting/annual_reports.shtml (2009 report,Retrived on June 10, 2011).

${ }^{8}$ We are extremely grateful to the A.C. Nielsen Co. for their extraordinary generosity in making this invaluable data available. It covers 52 weeks ending December 27, 2008, and December 29, 2007.

${ }^{9}$ For those stores for which, during a week, there were feature ads, coupon ads, display, or temporary price decrease of at least $5 \%$.
} 
and unit sales.

The men's shaving cream market recorded \$ 191 million sales in 2008. It runs the gamut of 11 different product segments of which only two are significant: gel (\$131 million) and foam (\$49) million ${ }^{10}$. In package size gel ranged from 1 to $14.8 \mathrm{oz}$, and foam from 2 to $14.8 \mathrm{oz}$.

In order to compare apples with apples, we found that the 7-oz gel and the 11-oz foam were by far the most popular sizes in their respective product category ${ }^{11}$.

\section{Theoretical Foundation for Determining Number of Clusters-And Their Meaning}

As already stated, a major purpose of this paper is to identify the market share leaders in each product segment (gel and foam) and determine the price-quality segment—based on price data—each is competing in.

Ketchen and Shook (1996) suggest that an a priori theory can be quite useful as a non-statistical tool for determining the number of clusters. However, an even more important question is being able to identify before-hand what those clusters or groups really mean, and what they stand for. Most consumer markets can be divided in three basic price-quality segments: premium, mid-price, and economy (Datta, 1996). These three basic segments can be extended to five with the addition of super-premium and ultra-economy segments. Thus three represents the minimum and five the maximum number of price-quality segments or groups for conducting cluster analysis in this study.

However, it is important to point out that some groups-price-quality segments-may consist of sub-groups. In such cases we may have more clusters than price-quality segments or groups (e.g., see Table 1).

Since 1973 economic inequality has sharply increased in America ${ }^{12}$. An important implication of this economic inequality is that it has distinctly increased the market size of the premium segment, and even the super-premium segment.

A socio-economic lifestyle profile of American households reveals six classes (Datta, 2012). Each class is associated with a price-quality segment typified by the retail stores where they generally shop: each a symbol of their lifestyle:

- The "Poor" (ultra-economy ${ }^{13}$ );

- The "Near Poor" (economy);

- The "Traditional Middle Class" (mid-price);

- The "Upper-Middle Class" (premium);

- The "The Very Rich/The Rich" (super-premium);

- The "Mega-Rich”-“Masters of the Universe”-(“price is no object”).

An empirical analysis of the U.S. toothpaste market found that it consisted of four price-quality segments: economy, mid-price, premium, and super-premium (Datta, 1996). P\&G, too, says that many markets in which it operates comprise the same four segments. However, $\mathrm{P} \& \mathrm{G}$ generally competes in all but the economy segment (Datta, 2010b).

\footnotetext{
10 The third in line was the cream segment with \$8.6 million in sales for 2008.

11 For 2008 7-oz gel cans accounted for $89 \%$ of total gel \$ sales, while 11 -oz foam cans were $78 \%$ of total foam \$ sales.

12 Although the U.S. economy and per-capita income have been growing since 1973, the median family income has virtually remained stagnant. While the average after-tax household income of the middle fifth rose $21 \%$ from 1979 to 2005 , for the top fifth it went up $80 \%$, and for the top 1\% a staggering 228\% (Datta, 2012).

13 The ultra-economy segment includes used household items that the poor often buy at thrift stores, and most merchandize sold by the "dollar" stores. However, as mentioned earlier, data from the "dollar" stores is not included in this study.
} 


\section{Hypotheses}

We offer two hypotheses about the market share leader for each of the two men's major shaving cream markets: gel and foam:

H1: That the market share leader would be a member of the mid-price segment, and

H2: That the market share leader would carry a price tag that is higher than that of the nearest competition.

\section{Guidelines for Cluster Consistency}

We have already laid down a theoretical foundation for the maximum (five) and minimum (three) number of groups - and what they signify in reality. In addition, we set up the following guidelines to enhance cluster reliability or consistency:

- As mentioned before, we have employed two clustering techniques—K Means and Hierarchical—to minimize researcher bias and enhance cluster reliability;

- Second, as much as possible, there should be a clean break between contiguous clusters ${ }^{14}$;

- Third, most of the time the above two procedures produced identical results. However, when that was not the case we chose the solution that produced membership of a cluster that was more stable from three-to-four or four-to-five clusters, and where there was a clean break between contiguous clusters;

- Fourth, the anchor clusters - the top and the bottom—should, in general, be robust. In a cluster analysis project limited to a range of three to five clusters, a robust cluster is one whose membership remains constant from three- to -four or four- to five-cluster solutions.

- Finally, we followed a step-by-step procedure to determine the optimal solution. First, we start with three clusters. Thus, the bottom cluster obviously becomes the economy segment and the top cluster the premium segment. Next we go to four clusters. If the bottom cluster remains unchanged we tentatively call the four clusters as: economy, mid-price, premium, and super-premium. Then we go to five clusters. If the membership of the bottom cluster still remains unchanged from what it was in the four-cluster result, it clearly implies that the ultra-economy segment does not exist and that the bottom cluster is the economy segment. After that if the membership of the top cluster also remains the same from a four- to a five-cluster answer, then the top cluster clearly becomes the super-premium segment. This means that in such a case we have a five-cluster solution with only four price-quality segments: economy, mid-price, premium, and super-premium. This implies that either the premium or the mid-price segment consists of two sub-segments (e.g., see Table 1).

\section{Results of Cluster Analysis}

The gel segment. For both 2008 (20 cases) and 2007 (20 cases) the five-cluster solution provides the best answer. However, the five clusters comprise only four price-quality segments in which the premium segment consists of two sub-segments: Premium I and Premium II (see Tables 1, 2).

So, how does the year 2007 compare with 2008? Out of a total of 20 brands for each year, this comparison is based on 19 cases that were common to both years. Surprisingly, there is a notable consistency between the results for the two years that are virtually identical ${ }^{15}$.

Interestingly, the number of brands in the premium segment is higher (eight for both years) than those in

\footnotetext{
${ }^{14}$ For example, for a five-cluster solution in the gel market for 2008 (see Table 1) the unit price for the top brand in the economy segment-Old Spice - is \$1.98, while the bottom brand in the next higher mid-price segment-Gillette Series-is \$ 2.40.

15 The only difference is an abrupt shift in the membership of two minor players: Bump Patrol and Bump Fighter. While both were part of the economy segment in 2007, the two have become members of the premium and mid-price segments, respectively, in 2008.
} 
the mid-price segment: six for 2008, and five for 2007. This is not surprising because, as we have already pointed out, with increasing economic inequality in America since 1973, one would expect the market for premium goods to go up sharply.

The foam segment. Compared to gel, which has 20 cases, the foam segment has a much smaller sample: 11 for 2008 and for 2007, or both 2008 and 2007 we considered the three-cluster result as the most realistic solution (see Tables 3, 4). Apart from the small sample size, another key factor in choosing this solution was that Noxzema was the sole brand that was a member of the top cluster from three- to four- to five-cluster solution.

As in the gel segment, there is a remarkable consistency in the overall competitive picture of the foam segment between the two years.

Table 1

Shaving Gel for Men (7 oz) 2008: Price-quality Segmentation-Hierarchical/KMeans Cluster Analysis

\begin{tabular}{|c|c|c|c|c|c|c|c|}
\hline $\begin{array}{l}\text { Price-quality } \\
\text { Segment }\end{array}$ & Brand Name & $\begin{array}{l}\text { Cluster } \\
\text { Center }\end{array}$ & \$MkShar\% & UMkShar\% & Uprice & \$PrmSales\% & UPrmSales\% \\
\hline \multirow[b]{2}{*}{ Super-premium } & Nxt & \multirow[b]{2}{*}{$\$ 4.87$} & 0.14 & 0.08 & $\$ 5.04$ & 18.12 & 19.63 \\
\hline & $\begin{array}{c}\text { Neutrogena } \\
\text { Razor Defense }\end{array}$ & & 2.54 & 1.48 & $\$ 4.69$ & 11.83 & 13.39 \\
\hline \multirow{6}{*}{ Premium I } & Neutrogena & \multirow{6}{*}{$\$ 3.79$} & 0.01 & 0.01 & $\$ 4.11$ & 2.66 & 5.33 \\
\hline & Aveeno & & 10.03 & 6.69 & $\$ 4.11$ & 11.79 & 13.34 \\
\hline & Every Man Jack & & 0.29 & 0.20 & $\$ 3.97$ & 7.09 & 7.80 \\
\hline & Adidas & & 0.00 & 0.00 & $\$ 3.91$ & 1.66 & 7.53 \\
\hline & $\begin{array}{l}\text { Gillette Comp. } \\
\text { Skincare }\end{array}$ & & 0.51 & 0.37 & $\$ 3.76$ & 17.65 & 24.22 \\
\hline & Clearasil & & 0.01 & 0.01 & $\$ 3.74$ & 10.83 & 24.04 \\
\hline \multirow{2}{*}{ Premium II } & Gillette Fusion & \multirow[b]{2}{*}{$\$ 3.36$} & 14.32 & 11.54 & $\$ 3.40$ & 35.13 & 41.69 \\
\hline & Bump Patrol & & 0.03 & 0.03 & $\$ 3.31$ & 3.49 & 6.16 \\
\hline \multirow{6}{*}{ Mid-price } & Nivea & \multirow{6}{*}{$\$ 2.63$} & 6.45 & 6.16 & $\$ 2.87$ & 17.38 & 19.44 \\
\hline & Gillette Mach 3 & & 4.49 & 4.40 & $\$ 2.79$ & 35.06 & 42.99 \\
\hline & Bump Fighter & & 0.00 & 0.00 & $\$ 2.68$ & 8.46 & 19.03 \\
\hline & Edge & & 34.03 & 35.90 & $\$ 2.60$ & 34.62 & 39.42 \\
\hline & Brut & & 0.12 & 0.13 & $\$ 2.44$ & 15.74 & 19.89 \\
\hline & Gillette Series & & 20.07 & 22.89 & $\$ 2.40$ & 33.75 & 39.04 \\
\hline \multirow{4}{*}{ Economy } & Old Spice & \multirow{4}{*}{$\$ 1.89$} & 0.50 & 0.69 & $\$ 1.98$ & 30.97 & 37.36 \\
\hline & Noxzema & & 1.89 & 2.70 & $\$ 1.92$ & 39.94 & 44.97 \\
\hline & $\begin{array}{c}\text { Private-label } \\
\text { group }\end{array}$ & & 4.14 & 6.09 & $\$ 1.86$ & 21.78 & 24.43 \\
\hline & Barbasol & & 0.41 & 0.63 & $\$ 1.80$ & 29.10 & 36.64 \\
\hline \multirow[b]{2}{*}{ Total Sales } & & \multirow[b]{2}{*}{$\$ 2.74$} & $100 \%$ & $100 \%$ & & $29.9 \%$ & $35.4 \%$ \\
\hline & & & $\$ 116,063,358$ & $42,351,415$ & $\$ 2.74$ & $\$ 34,652,211$ & $15,000,413$ \\
\hline
\end{tabular}

Notes: ${ }^{\mathrm{a}} \mathrm{F}$ statistic $=170$, significant at .000 level. ${ }^{\mathrm{b}}$ Cluster Center means average group price per unit.

\section{Hypotheses Testing: Identifying Market Share Leader}

Now it is time to delve deeper into the competitive picture of the gel and foam segments. Although market share can be defined both in units and in dollars, number of units has to be considered as the primary dimension. The null hypotheses are:

a) That the market share leader would not be a member of the mid-price segment, and

b) That the market share leader would not carry a price tag that is higher than that of the nearest 
competition.

\section{The Gel Segment}

A clear-cut market share leader is Edge: with a market share of $35.9 \%$ in unit sales for 2008 (see Table 1), and 37.8\% for 2007 (see Table 2). It is also the undisputed market share leader in dollar sales. Its nearest competitor is Gillette Series which is significantly behind, with a market share of $22.9 \%$ for 2008 and $21 \%$ for 2007. Both are members of the mid-price-segment for 2008 and 2007, as hypothesized. It is clear that the Gillette Co., a powerhouse in the shaving business, was unable to overcome the disadvantage of competing against the first-mover S.C. Johnson's Edge even after Edge lost its patent protection in 1987, as mentioned before.

The average (net) unit price for Edge is $\$ 2.60$ and \$2.57, respectively, for 2008 and 2007. The corresponding figures for Gillette Series are \$2.40 and \$2.42: prices that are lower than those of Edge.

Thus, we must reject both the null hypotheses.

Table 2:

Shaving Gel for Men (7 oz) 2007: Price-quality Segmentation-Hierarchical Cluster Analysis

\begin{tabular}{|c|c|c|c|c|c|c|c|}
\hline $\begin{array}{l}\text { Price-quality } \\
\text { Segment }\end{array}$ & Brand Name & $\begin{array}{l}\text { Cluster } \\
\text { Center } \\
\end{array}$ & \$MkShar\% & $\begin{array}{c}\text { UMkShar } \\
\% \\
\end{array}$ & Uprice & $\begin{array}{c}\text { \$PrmSales } \\
\%\end{array}$ & $\begin{array}{c}\text { UPrmSales } \\
\% \\
\end{array}$ \\
\hline Super-premium & $\begin{array}{l}\text { Neutrogena Razor } \\
\text { Defense }\end{array}$ & $\$ 4.67$ & 2.7 & 1.57 & $\$ 4.67$ & 16.20 & 18.79 \\
\hline \multirow{6}{*}{ Premium I } & $\begin{array}{l}\text { High Time Bump } \\
\text { Stopper }\end{array}$ & \multirow{6}{*}{$\$ 4.00$} & 0.01 & 0.00 & $\$ 4.25$ & 2.31 & 2.85 \\
\hline & Every Man Jack & & 0.16 & 0.10 & $\$ 4.07$ & 26.17 & 27.20 \\
\hline & Clearasil & & 0.09 & 0.06 & $\$ 4.03$ & 17.66 & 28.83 \\
\hline & Aveeno & & 10.39 & 7.12 & $\$ 3.95$ & 8.99 & 10.25 \\
\hline & Neutrogena & & 0.29 & 0.21 & $\$ 3.86$ & 27.48 & 36.93 \\
\hline & $\begin{array}{l}\text { Gillette Comp. } \\
\text { Skincare }\end{array}$ & & 1.03 & 0.73 & $\$ 3.83$ & 16.14 & 21.50 \\
\hline \multirow{2}{*}{ Premium II } & Adidas & \multirow{2}{*}{$\$ 3.33$} & 0.00 & 0.00 & $\$ 3.40$ & 17.24 & 21.73 \\
\hline & Gillette Fusion & & 13.47 & 11.14 & $\$ 3.27$ & 36.11 & 43.22 \\
\hline \multirow{5}{*}{ Mid-price } & Gillette Mach 3 & \multirow{5}{*}{$\$ 2.60$} & 4.45 & 4.21 & $\$ 2.87$ & 26.67 & 33.48 \\
\hline & Nivea & & 5.27 & 5.19 & $\$ 2.75$ & 11.86 & 14.36 \\
\hline & Edge & & 35.84 & 37.80 & $\$ 2.57$ & 28.44 & 32.82 \\
\hline & Gillette Series & & 18.79 & 21.00 & $\$ 2.42$ & 32.17 & 36.98 \\
\hline & Brut & & 0.14 & 0.16 & $\$ 2.40$ & 15.57 & 22.01 \\
\hline \multirow{6}{*}{ Economy } & Old Spice & \multirow{6}{*}{$\$ 1.77$} & 0.61 & 0.87 & $\$ 1.89$ & 33.04 & 41.09 \\
\hline & Noxzema & & 1.55 & 2.23 & $\$ 1.88$ & 42.46 & 46.91 \\
\hline & Private-label group & & 4.54 & 6.57 & $\$ 1.87$ & 20.25 & 22.58 \\
\hline & Bump Patrol & & 0.01 & 0.01 & $\$ 1.75$ & 12.80 & 26.34 \\
\hline & Barbasol & & 0.64 & 1.01 & $\$ 1.72$ & 30.35 & 39.02 \\
\hline & Bump Fighter & & 0.01 & 0.02 & $\$ 1.49$ & 29.43 & 47.32 \\
\hline \multirow[b]{2}{*}{ Total Sales } & & \multirow[b]{2}{*}{$\$ 2.71$} & $100 \%$ & $100 \%$ & & $26.6 \%$ & $31.8 \%$ \\
\hline & & & $\$ 116,324,092$ & $42,982,179$ & $\$ 2.71$ & $30,933,383$ & $13,657,817$ \\
\hline
\end{tabular}

Note. ${ }^{\mathrm{a}} \mathrm{F}$ statistic $=172$, significant at .000 level.

\section{The Foam Segment}

The brand with the highest market share is Barbasol with $47.6 \%$ in unit sales for 2008 (see Table 3), and 42.7\% for 2007 (see Table 4). Its nearest competitor is Gillette Foamy, with a market share of 35.9\% for 2008 and $35.8 \%$ for 2007 .

But, in contradiction to our hypothesis, Barbasol is a member of the economy rather than the mid-price 
segment. However, Gillette Foamy is part of the mid-price segment.

The average unit price for Barbasol is \$1.28 and \$1.17, respectively, for 2008 and 2007. But the corresponding figures for Gillette Foamy are much higher at \$1.89 and \$1.82.

Thus, we cannot reject either null hypothesis.

Now if we consider market share in dollars the winner is Gillette Foamy with $44.1 \%$ for 2008 , and $44.6 \%$ for 2007, compared to $39.6 \%$ and $34.2 \%$, respectively, for Barbasol. Although sales in dollars is not the primary measure of market share, yet it can provide useful information about which brand is likely to be more profitable in terms of gross margin.

Table 3

Shaving Cream for Men-Foam (11 oz) 2008: Price-quality Segmentation-Hierarchical Cluster Analysis

\begin{tabular}{|c|c|c|c|c|c|c|c|}
\hline $\begin{array}{c}\text { Price-quality } \\
\text { Segment }\end{array}$ & Brand Name & $\begin{array}{l}\text { Cluster } \\
\text { Center }\end{array}$ & \$MkShar\% & UMkShar\% & Uprice & \$PrmSales\% & UPrmSales\% \\
\hline Premium & Noxzema & $\$ 2.24$ & 7.24 & 4.99 & $\$ 2.24$ & 17.01 & 21.62 \\
\hline \multirow{3}{*}{ Mid-price } & Gillette Foamy & \multirow[b]{3}{*}{$\$ 1.69$} & 44.05 & 35.93 & $\$ 1.89$ & 12.34 & 15.87 \\
\hline & Private-label I & & 1.45 & 1.37 & $\$ 1.63$ & 35.17 & 37.46 \\
\hline & Brut & & 0.06 & 0.06 & $\$ 1.53$ & 12.79 & 21.78 \\
\hline \multirow{7}{*}{ Economy } & Private-label II & \multirow{7}{*}{$\$ 1.11$} & 0.19 & 0.22 & $\$ 1.34$ & 10.97 & 12.89 \\
\hline & Barbasol & & 39.59 & 47.56 & $\$ 1.28$ & 18.11 & 21.57 \\
\hline & Colgate & & 0.19 & 0.24 & $\$ 1.24$ & 7.01 & 9.63 \\
\hline & Old Spice & & 6.60 & 8.67 & $\$ 1.17$ & 14.45 & 15.88 \\
\hline & Personal Care & & 0.60 & 0.92 & $\$ 1.00$ & 9.67 & 10.42 \\
\hline & Rise & & 0.00 & 0.00 & $\$ 0.94$ & 6.81 & 7.71 \\
\hline & Percara & & 0.00 & 0.00 & $\$ 0.79$ & 26.71 & 41.08 \\
\hline \multirow{2}{*}{ Total Sales } & & \multirow[b]{2}{*}{$\$ 1.54$} & $100 \%$ & $100 \%$ & & $15.4 \%$ & $19.1 \%$ \\
\hline & & & $\$ 38,465,208$ & $24,947,382$ & $\$ 1.54$ & $\$ 5,926,454$ & $4,763,927$ \\
\hline
\end{tabular}

Notes: ${ }^{\mathrm{a}} \mathrm{F}$ statistic $=20$, significant at .001 level. ${ }^{\mathrm{b}}$ Excludes Burma Shave because of a very small level of sales for 2008 (\$145).

Question mark behind Barbasol's market share leadership? It is easy to realize why the mighty Gillette's Series brand lost the market share war to S.C. Johnson's powerful first-mover Edge brand in the men's shaving gel market. But how can one explain the puzzle that a much weaker rival Barbasol was able to move ahead of Gillette Foamy and grab the market share leadership in the men's shaving foam market?

We submit that the most plausible explanation for this seems to be that perhaps the Gillette Co. saw market share leadership as a means not an end. So, if they wished Gillette Foamy to become the market share leader they could easily have done so by lowering its price to a level that was not so far from Barbasol's. However, such a strategy would have been a lot less profitable than Gillette's current strategy. Instead, the company appears to have chosen a smarter strategy that seems much more profitable.

It is important to point out that the shaving gel segment was far more competitive, and so price competition was more intense than in the foam segment. Because the foam market was much smaller and was steadily losing relative market share to the gel segment, it was not attracting major competitors. Even Colgate decided to quit the segment in 2008 (Tickner, 2009). In this segment the only major player besides Gillette Foamy was a much weaker competitor Barbasol. So, Gillette Co. positioned Gillette Foamy at the upper end of the mid-price segment that was very close to the premium segment. The end result is that while Gillette Foamy did lose the market share leadership to Barbasol in units, it became the market share leader in sales dollars. To generate the same dollar sales in 2008 as Gillette Foamy, Barbasol would have to sell about half as many more (48\%) units than the Gillette brand! 
Table 4

Shaving Cream for Men-Foam (11 oz) 2007: Price-quality Segmentation-KMeans/Hierarchical Cluster Analysis

\begin{tabular}{|c|c|c|c|c|c|c|c|}
\hline $\begin{array}{c}\text { Price-quality } \\
\text { Segment }\end{array}$ & Brand Name & $\begin{array}{l}\text { Cluster } \\
\text { Center }\end{array}$ & \$MkShar\% & UMkShar\% & Uprice & $\begin{array}{c}\text { \$PrmSales } \\
\%\end{array}$ & UPrmSales\% \\
\hline Premium & Noxzema & $\$ 2.23$ & 8.11 & 5.32 & $\$ 2.23$ & 7.10 & 4.5 \\
\hline \multirow{3}{*}{ Mid-price } & Gillette Foamy & \multirow{3}{*}{$\$ 1.65$} & 44.59 & 35.77 & $\$ 1.82$ & 40.98 & 33.7 \\
\hline & Brut & & 0.27 & 0.25 & $\$ 1.59$ & 0.27 & 0.3 \\
\hline & $\begin{array}{c}\text { Private-label } \\
\text { I }\end{array}$ & & 1.83 & 1.75 & $\$ 1.53$ & 2.17 & 1.8 \\
\hline \multirow{7}{*}{ Economy } & Old Spice & \multirow{7}{*}{$\$ 1.09$} & 5.69 & 6.58 & $\$ 1.26$ & 5.68 & 5.7 \\
\hline & $\begin{array}{l}\text { Private-label } \\
\text { II }\end{array}$ & & 0.11 & 0.13 & $\$ 1.26$ & 0.14 & 0.2 \\
\hline & Barbasol & & 34.20 & 42.72 & $\$ 1.17$ & 37.73 & 43.3 \\
\hline & Colgate & & 4.67 & 6.73 & $\$ 1.01$ & 5.73 & 10.2 \\
\hline & Personal Care & & 0.35 & 0.51 & $\$ 1.00$ & 0.12 & 0.1 \\
\hline & Percara & & 0.13 & 0.20 & $\$ 0.99$ & 0.08 & 0.1 \\
\hline & Rise & & 0.04 & 0.06 & $\$ 0.95$ & 0.01 & 0.0 \\
\hline \multirow[b]{2}{*}{ Total Sales } & & \multirow[b]{2}{*}{$\$ 1.46$} & $100 \%$ & $100 \%$ & & $18.1 \%$ & $23.4 \%$ \\
\hline & & & $\$ 38,174,407$ & $26,144,741$ & $\$ 1.46$ & $\$ 6,922,880$ & $6,107,524$ \\
\hline
\end{tabular}

Notes: ${ }^{\mathrm{a}} \mathrm{F}$ statistic $=39$, significant at .000 level. ${ }^{\mathrm{b}}$ Excludes Burma Shave because of a tiny level of sales (\$45).

To sum up. Although technically the result of cluster analysis involving the foam shaving cream market was negative, we think it does not necessarily negate our hypothesis that market share leaders in most consumer markets are very likely to compete in the mid-price segment at a price somewhat higher than that of the competition. We submit that although Barbasol was able to capture the market share leadership mantle in the shaving foam segment, it was in large part because Gillette Co. seems to have facilitated this process by following a path that may have been somewhat short on market share but was likely to be long on profitability.

\section{The Role of Promotion}

In the gel market promotional sales represented a substantial proportion of total sales. In 2008 they accounted for $29.9 \%$ in dollars and $35.4 \%$ in units (see Table 1). For 2007 the corresponding figures were $26.6 \%$ and 31.8\% (see Table 2).

Promotional sales, however, were much lower in the foam segment. The comparable figures were $15.4 \%$ and 19.1\% for 2008 (see Table 3), and 18.1\% and 23.4\% for 2007 (see Table 4).

\section{Strong Correlation Between Promotional Sales and Total Sales}

We performed correlation analysis for 2008 and 2007 between total sales and promotional sales both in dollars and in units for both gel and foam. In every case the result showed a strong positive correlation that was significant at the 0.01 level.

Next, we looked at the extent to which each brand relied on sales from promotional discounts. To address this matter requires answering two questions. One is what proportion of units was sold for each brand at a discount? The other is how deep was the discount (as measured by the average promotional unit price as a percentage of the average non-promotional unit price)? If we multiply the above two ratios we can get a composite which can be called an index of promotional sales ${ }^{16}$.

\footnotetext{
${ }^{16}$ An alternate way to compute this index is to take the total figure of promotional dollar sales and express it as a percentage of what total dollar sales would have been if all the units were sold without any promotion (total actual unit sales times average non-promotional unit price).
} 


\section{Strong Correlation Between Unit Price Rank Data for 2008 and 2007}

We wondered how stable the relative price position of a brand from 2007 to 2008 was. So, we ranked each of the gel and foam brands (common to both years) in terms of average unit price and performed correlation analysis on this ordinal data. Surprisingly — for both the gel and foam segments—-the Spearman's rho as well as Kendall's tau_b coefficient was significant at the 0.01 level.

These results suggest that in the men's shaving cream market each brand has tried to maintain its relative price position compared to its nearest competitors from 2007 and 2008. This implies that in this market management has generally considered price as a strategic rather than a tactical variable.

The implication of the above results is that relative price at which a brand wishes to compete is of strategic importance not only for the market share leader—as we have hypothesized here-but for all brands that compete in that market.

\section{Index of Promotional Sales}

The gel segment. A three-cluster K-Means analysis produced three groups. For 2008 the "heavy” group includes the market-share leader Edge, and all three Gillette brands (Series, Fusion, and Mach3) with almost identical scores. The "moderate" category includes the private-label group and Nivea. Finally, in the third group, which we call "light," are Aveeno and Neutrogena Razor Defense. The results for 2007 are generally comparable to those for 2008. ${ }^{17}$ Average brand scores for key players for the two years are shown in Table 5 .

From the above information, it is clear that the top-selling mid-price brands-Edge and Gillette Series - and even economy brands Noxzema and Old Spice, depend heavily on discounting to maintain their market share. In addition, Gillette Fusion, which has the highest market share in the premium gel segment, has the promotional sales index that is identical to that of Edge and Gillette Series.

In contrast, Aveeno, which is positioned at the upper-end of the premium segment, and Neutrogena Razor Defense, which is a member of the super-premium segment, belong to the "light" promotion group. These two brands are owned by Johnson \& Johnson. The "light” promotional footprint implies that the company does not want to dilute the "high-price" image of its brands by engaging in a lot of discounting.

The foam segment. In Table 6 we present an average index for the two years for key brands. Based on this data we think all five brands belong to the "moderate" group.

Table 5

Shaving Gel for Men 2008, 2007: Promotional Sales Index and Intensity Rating—Key Players

\begin{tabular}{|c|c|c|c|c|}
\hline Brand Name & \begin{tabular}{|l|} 
Promotional \\
Sales Index 2008 \\
\end{tabular} & \begin{tabular}{|l|} 
Promotional \\
Sales Index 2007
\end{tabular} & $\begin{array}{l}\text { Av. Promo Sales Index: } \\
2008 \text { and } 2007\end{array}$ & $\begin{array}{l}\text { Av. Promo Sales Intensity } \\
\text { Rating: } 2008 \text { and } 2007\end{array}$ \\
\hline Noxzema & 0.37 & 0.39 & 0.38 & \multirow{7}{*}{ “Heavy” } \\
\hline Edge & 0.32 & 0.27 & 0.30 & \\
\hline Gillette Fusion & 0.32 & 0.32 & 0.32 & \\
\hline Gillette Series & 0.31 & 0.30 & 0.31 & \\
\hline Gillette Mach3 & 0.31 & 0.24 & 0.28 & \\
\hline Old Spice & 0.28 & 0.29 & 0.29 & \\
\hline Barbasol & 0.26 & 0.27 & 0.27 & \\
\hline Private-label group & 0.21 & 0.20 & 0.21 & \multirow{2}{*}{ "Moderate" } \\
\hline Nivea & 0.17 & 0.12 & 0.15 & \\
\hline Neutrogena Razor Defense & 0.12 & 0.16 & 0.14 & \multirow{2}{*}{ "Light" } \\
\hline Aveeno & 0.12 & 0.09 & 0.11 & \\
\hline
\end{tabular}

${ }^{17}$ Except for Neutrogena Razor Defense which joined the “moderate” group, and Nivea which fell into the "light” group. 


\section{Advertising Not a Major Factor in Both Gel and Foam Segments}

The 2008 gel data (see Table 7) reveals only three brands—Edge, Gillette Fusion, and Nivea-while the 2007 data shows only two brands-Edge and Gillette Fusion.

For 2008 Edge spent more than \$14 million on advertising—about 36\% of its sales—a number that was up sharply from \$3.3 million in 2007 (about 8\% of sales).

Table 6

Shaving Cream for Men—Foam 2008, 2007: Promotional Sales Index and Intensity Rating—Key Players

\begin{tabular}{|l|c|c|c|c|}
\hline Brand Name & $\begin{array}{l}\text { Promotional } \\
\text { Sales Index 2008 }\end{array}$ & $\begin{array}{l}\text { Promotional } \\
\text { Sales Index 2007 }\end{array}$ & $\begin{array}{l}\text { Average Promotional Sales } \\
\text { Index: 2008 and 2007 }\end{array}$ & $\begin{array}{l}\text { Average Promotional Sales } \\
\text { Intensity Rating: 2008 and 2007 }\end{array}$ \\
\hline Barbasol & 0.17 & 0.19 & 0.18 & \multirow{3}{*}{ "Moderate” } \\
\hline Noxzema & 0.16 & 0.15 & 0.16 & \\
\hline Old Spice & 0.14 & 0.18 & 0.16 & \\
\hline Gillette Foamy & 0.12 & 0.16 & 0.13 & \\
\hline Colgate & 0.07 & 0.19 &
\end{tabular}

Table 7

Shaving Gel for Men: Advertising Data for 2008, 2007

\begin{tabular}{|l|l|l|r|l|l|r|l|}
\hline Brand Name & $\begin{array}{l}\text { Brand Advtg } \\
\text { Expenses 2008 }\end{array}$ & $\begin{array}{l}\text { Total Sales } \\
2008\end{array}$ & $\begin{array}{l}\text { Advtg as \% } \\
\text { of } \\
\text { Sales2008 }\end{array}$ & $\begin{array}{l}\text { Brand Advtg } \\
\text { Expenses2007 }\end{array}$ & $\begin{array}{l}\text { Total Sales } \\
2007\end{array}$ & $\begin{array}{l}\text { Advtg as \% of } \\
\text { Sales 2007 }\end{array}$ & $\begin{array}{l}\text { Joint Advertising } \\
2007\end{array}$ \\
\hline Edge & $\$ 14,146,000$ & $\$ 39,497,934$ & $35.8 \%$ & $\$ 3,310,000$ & $\$ 41,685,882$ & $7.9 \%$ & \\
\hline Gillette Fusion & $\$ 128,000$ & $\$ 16,624,404$ & $0.8 \%$ & $\$ 3,886,000$ & $\$ 15,668,960$ & $24.8 \%$ & $\$ 2,941,000$ \\
\hline Nivea & $\$ 3,326,000$ & $\$ 7,491,634$ & $44.3 \%$ & & & & \\
\hline
\end{tabular}

Gillette Fusion's advertising expenses for 2008 were a mere $\$ 128,000$. But, the brand's advertising outlay in 2007 was $\$ 3.9$ million that was about $25 \%$ of its sales.

Nivea forked out about $\$ 3.3$ million on advertising in 2008 that works out to about $44 \%$ of its sales. However, for 2007 it didn't spend any money on advertising.

For the foam segment (see Table 8) Barbasol is the only brand to rely on advertising. It spent about \$1.3 million in $2008-8.4 \%$ of sales. For 2007 , though, its advertising expenditure was only $\$ 128,000$ that is $1 \%$ of its sales.

Table 8

Shaving Cream for Men-Foam: Advertising Data for 2008, 2007

\begin{tabular}{|l|l|l|l|l|l|l|c|}
\hline Brand Name & $\begin{array}{l}\text { Brand Advtg } \\
\text { Expenses 2008 }\end{array}$ & $\begin{array}{l}\text { Total Sales } \\
2008\end{array}$ & $\begin{array}{l}\text { Advtg as \% of } \\
\text { Sales 2008 }\end{array}$ & $\begin{array}{l}\text { Brand Advtg } \\
\text { Expenses 2007 }\end{array}$ & $\begin{array}{l}\text { Total Sales } \\
2007\end{array}$ & $\begin{array}{l}\text { Advtg as \% of } \\
\text { Sales 2007 }\end{array}$ & $\begin{array}{l}\text { Joint Advertising } \\
2007\end{array}$ \\
\hline Barbasol & $\$ 1,277,000$ & $\$ 15,228,984$ & $8.4 \%$ & $\$ 128,000$ & $\$ 13,057,310$ & $1 \%$ & None \\
\hline
\end{tabular}

From this picture we can draw the following broad conclusions:

- In general, advertising did not play an important role in both the gel and the foam markets during 2008 and 2007. One reason seems to be that the men's shaving cream is a mature market that has not seen much innovation for a long time. So, there is not a lot to talk about, except when a brand introduces a new flavor, or when a company introduces an entirely new brand (e.g., Gillette Fusion).

- As indicated above, there has been a vast variation between advertising efforts from one year to the next.

- The industry executives rely primarily on promotional discounting and coupons to gain sales. 


\section{Promotion Much More Intensive in the Gel Segment}

There seem to be two main reasons why there is much more discounting in the gel segment vs. the foam (Table 5 vs. Table 6). As stated earlier, the foam market is much smaller and has been steadily losing relative market share to the gel segment. So, the gel market has attracted a large number of brands, and therefore is much more competitive. Another reason is that there appears to be greater margin in selling gel than foam. For example, for 2008 the average price of a 7-oz can of gel was $\$ 2.74$ (see Table 1), while the corresponding figure for an $11-\mathrm{oz}$ can of foam was $56 \%$ of this figure at $\$ 1.54$ (see Table 3$)^{18}$. Although gel brands are generally marketed with higher and more expensive ingredients than foam, nevertheless, there seems far less room for a discount in selling foam than in selling gel.

\section{Major Competitive Groups: By Level of Market Share}

The gel segment. Table 9 contains a profile of major groups for the gel segment for 2008 and 2007 combined. The groups are classified by level of market share: low, moderate, and high.

The gel segment reveals three groups. The "low" market share group shows three major companies:

- J\&J with its focus on the upper-price segments.

- Beiersdorf's Nivea and Gillette Mach3 competing at the upper-end of the mid-price segment.

- The private-label group competing in the economy segment.

The lone member of the "moderate" group is P\&G's Gillette Fusion which has positioned itself at the lower-end of the premium segment.

The "high" market share group has two members both competing in the mid-price segment: the market share leader Edge, followed by Gillette Series.

Table 9

The U.S. Men's Shaving Gel Market 2008 and 2007: Major Groups by Level of Market Share

\begin{tabular}{|c|c|c|c|c|c|c|c|}
\hline Corporate Identity & Competitive Strategy & $\begin{array}{c}\text { Level of } \\
\text { market share }\end{array}$ & Brand Name & PQ Segment & $\begin{array}{l}\text { Av. } \\
\text { Uprice }\end{array}$ & $\begin{array}{l}\text { Av. Mkt } \\
\text { Share \% }\end{array}$ & $\begin{array}{l}\text { Promotion } \\
\text { Intensity }\end{array}$ \\
\hline \multirow[t]{2}{*}{\begin{tabular}{|l} 
Johnson \& \\
Johnson
\end{tabular}} & \multirow{2}{*}{$\begin{array}{l}\text { Focus on the upper-price } \\
\text { segments }\end{array}$} & \multirow{8}{*}{ Low } & \begin{tabular}{|l|} 
Neutrogena \\
Razor Defense
\end{tabular} & Super-premium & $\$ 4.68$ & 1.5 & \multirow[t]{2}{*}{ “Light” } \\
\hline & & & Aveeno & Premium (upper) & $\$ 4.03$ & 6.9 & \\
\hline Beiersdorf & \multirow{2}{*}{$\begin{array}{l}\text { Compete at the upper-end } \\
\text { of the mid-price segment }\end{array}$} & & Nivea & \multirow{2}{*}{ Mid-price } & $\$ 2.81$ & 5.7 & "Moderate" \\
\hline P\&G & & & Gillette Mach3 & & $\$ 2.83$ & 4.3 & "Heavy” \\
\hline Private-label group & \multirow{4}{*}{$\begin{array}{l}\text { Compete in the economy } \\
\text { segment }\end{array}$} & & Store brands & \multirow{4}{*}{ Economy } & $\$ 1.87$ & 6.4 & "Moderate" \\
\hline Perio & & & Barbasol & & $\$ 1.76$ & 0.8 & \multirow{3}{*}{ "Heavy” } \\
\hline \multirow{2}{*}{$P \& G$} & & & Noxzema & & $\$ 1.90$ & 2.5 & \\
\hline & & & Old Spice & & $\$ 1.94$ & 0.8 & \\
\hline \multirow[b]{2}{*}{ P\&G (Gillette) } & $\begin{array}{l}\text { To be a market share leader } \\
\text { in the premium segment }\end{array}$ & Moderate & Gillette Fusion & Premium (lower) & $\$ 3.34$ & 11.3 & \multirow{3}{*}{ “Heavy” } \\
\hline & $\begin{array}{l}\text { To compete in the mid-price } \\
\text { segment and hold a } \\
\text { "leadership or significant } \\
\text { market share position" }\end{array}$ & \multirow[t]{2}{*}{ High } & Gillette Series & Mid-price & $\$ 2.41$ & 22.0 & \\
\hline S. C. Johnson & $\begin{array}{l}\text { To compete in the mid-price } \\
\text { segment and be the market } \\
\text { share leader }\end{array}$ & & Edge & & $\$ 2.59$ & 36.9 & \\
\hline
\end{tabular}

\footnotetext{
${ }^{18}$ We are assuming that the 7-oz gel can and $11 \mathrm{oz}$ aerosol foam can provide roughly the same number of shaves.
} 
Table 10

The U.S. Men's Shaving Cream Market_Foam-2008 and 2007: Major Groups by Level of Market Share

\begin{tabular}{|c|c|c|c|c|c|c|c|}
\hline \multirow{2}{*}{$\begin{array}{l}\text { Corporate } \\
\text { Group }\end{array}$} & \multirow{2}{*}{ Competitive Strategy } & \multirow{2}{*}{$\begin{array}{l}\text { Level of } \\
\text { market } \\
\text { share }\end{array}$} & \multirow{2}{*}{ Brand Name } & \multicolumn{2}{|c|}{$\begin{array}{l}\text { Competitive } \\
\text { Strategy }\end{array}$} & \multirow{2}{*}{$\begin{array}{c}\text { Av. } \\
\text { mkt } \\
\text { share } \\
\%\end{array}$} & \multirow{2}{*}{$\begin{array}{l}\text { Promotiona } \\
\text { Intensity }\end{array}$} \\
\hline & & & & $\begin{array}{c}\text { PQ } \\
\text { segment }\end{array}$ & $\begin{array}{l}\text { Av. } \\
\text { unit } \\
\text { price }\end{array}$ & & \\
\hline $\begin{array}{c}\text { P\&G } \\
\text { (Gillette) }\end{array}$ & $\begin{array}{l}\text { To compete in the mid-price } \\
\text { segment and hold a } \\
\text { "leadership or significant } \\
\text { market share position" }\end{array}$ & \multirow[t]{2}{*}{ High } & $\begin{array}{l}\text { Gillette } \\
\text { Foamy }\end{array}$ & Mid-price & $\$ 1.86$ & $35.9 \%$ & "Moderate" \\
\hline Perio & $\begin{array}{l}\text { Compete in the economy } \\
\text { segment and be the market } \\
\text { share leader }\end{array}$ & & Barbasol & Economy & $\$ 1.23$ & $45.1 \%$ & "Moderate" \\
\hline \multirow{2}{*}{ P\&G (Other) } & $\begin{array}{c}\text { Compete in the premium } \\
\text { segment }\end{array}$ & \multirow{4}{*}{ Low } & Noxzema & Premium & $\$ 2.24$ & $5.2 \%$ & \multirow{2}{*}{ "Moderate" } \\
\hline & $\begin{array}{c}\text { Compete in the economy } \\
\text { segment }\end{array}$ & & Old Spice & Economy & $\$ 1.22$ & $7.6 \%$ & \\
\hline \multirow{2}{*}{$\begin{array}{l}\text { Private-label } \\
\text { group }\end{array}$} & $\begin{array}{c}\text { Compete in the mid-price } \\
\text { segment }\end{array}$ & & Group I & Mid-price & $\$ 1.58$ & $1.6 \%$ & $\begin{array}{l}\text { "Heavy” } \\
(2008) \\
\end{array}$ \\
\hline & $\begin{array}{c}\text { Compete in the economy } \\
\text { segment }\end{array}$ & & Group II & Economy & $\$ 1.30$ & $0.2 \%$ & $\begin{array}{l}\text { "Light" } \\
\text { (2008) }\end{array}$ \\
\hline
\end{tabular}

The foam segment. In the foam segment there are two groups (see Table 10). The "high" market share group includes the market share leader Barbasol, and Gillette Foamy. In the "low" market share group the major competitors are P\&G's Old Spice competing in the economy segment, and P\&G’s Noxzema, a member of the premium segment.

P\&G sold Noxzema to Alberto Culver in $2008^{19}$.

\section{Identifying Strategic Groups in the Men’s Shaving Cream Market}

Table 11 shows the primary area or industrial background of each major corporation, the technological expertise that allowed it to enter the shaving cream market, and the NAICS ${ }^{20}$ codes of markets in which the company has a major presence.

Table 11

The U.S. Men's Shaving Cream Market-Technological Competence of Major Corporate Groups

\begin{tabular}{|c|c|c|c|c|c|c|}
\hline $\begin{array}{l}\text { Name of } \\
\text { Parent Co. }\end{array}$ & $\begin{array}{l}\text { Year } \\
\text { Founded }\end{array}$ & $\begin{array}{l}\text { Primary Area of } \\
\text { Technological } \\
\text { Competence }\end{array}$ & Brand Name & $\begin{array}{l}\text { Source of Technological } \\
\text { Expertise for Entry in the } \\
\text { Shaving Cream Market }\end{array}$ & Major Industry Classification & $\begin{array}{l}\text { NAICS } \\
\text { Code }\end{array}$ \\
\hline Beiersdorf & 1911 & Skin Care & Nivea & Skin Care & Toilet Preparation Mfg. & 32562 \\
\hline \multirow{2}{*}{\begin{tabular}{|l|} 
Johnson \& \\
Johnson
\end{tabular}} & \multirow{2}{*}{1887} & \multirow[t]{2}{*}{ Pharmaceuticals } & Aveeno & Dermatology & Pharmaceutical \& Medicine Mfg. & 32541 \\
\hline & & & Neutrogena & Skin Care & Toilet Preparation Mfg & 32562 \\
\hline \begin{tabular}{|l} 
P\&G \\
(Gillette)
\end{tabular} & 1901 & Men’s Shaving & \begin{tabular}{|l|} 
Gillette Series \\
Gillette Mach 3 \\
Gillette Fusion \\
Gillette Foamy
\end{tabular} & Men’s Shaving & $\begin{array}{l}\text { Safety Razors \& Blades } \\
\text { Toilet Preparation Mfg. }\end{array}$ & $\begin{array}{r}332211 \\
32562\end{array}$ \\
\hline \multirow{2}{*}{$\begin{array}{l}\text { P\&G } \\
\text { (other brands) }\end{array}$} & \multirow{2}{*}{1905} & \multirow{2}{*}{$\begin{array}{l}\text { Soap \& } \\
\text { Detergents }\end{array}$} & Noxzema & Skin Care & Toilet Preparation Mfg. & \multirow{2}{*}{32562} \\
\hline & & & Old Spice & Skin Care & Toilet Preparation Mfg. & \\
\hline Perio & 1903 & Shaving Cream & Barbasol & Men's Shaving & Toilet Preparation Mfg. & 32562 \\
\hline S. C. Johnson & 1886 & \begin{tabular}{|l} 
Chemical \\
Industry
\end{tabular} & Edge & Household Chemicals & $\begin{array}{l}\text { Soap \& Cleaning Compound Mfg. } \\
\text { Toilet Preparation Mfg. }\end{array}$ & $\begin{array}{l}32561 \\
32562\end{array}$ \\
\hline
\end{tabular}

19 http://www.marketwatch.com/story/alberto-culver-buys-rights-to-noxzema-brand ( Retrieved on June 10, 2011).

20 North American Industrial Classification System. 
Finally, based on all the information we have reported and discussed above, we present (see Table 12) a competitive profile of strategic groups in the U.S. men's shaving cream market which identifies six corporations. We discuss each of them below.

\section{Procter \& Gamble (P\&G)}

$P \& G$ is the leading consumer products company in the world. The original expertise of $P \& G$ was in soaps and detergents: a technology that plays an important role in making men's shaving cream. Also with the acquisition of the Gillette Co. in 2005, P\&G has become the predominant player in the Shaving business.

As far as the shaving cream market as a whole is concerned, it is clear from Table 12 that $P \& G$ is the biggest competitor in this market. It has the widest business scope- both horizontally and vertically. Besides Perio and the private-label group, it is the only major company that is competing in both the gel and the foam segments; also it has a presence in three out of four price-quality segments: premium, mid-price, and economy.

Table 12

Strategic Groups in the U.S. Men's Shaving Cream Market-2008, 2007: A Competitive Profile

\begin{tabular}{|c|c|c|c|c|c|c|c|c|}
\hline \multirow[t]{2}{*}{$\begin{array}{l}\text { Strategic } \\
\text { Group }\end{array}$} & \multirow{2}{*}{\begin{tabular}{|c|} 
Source of \\
entry into \\
men's shaving \\
cream market
\end{tabular}} & \multicolumn{2}{|c|}{ Business scope } & \multirow[t]{2}{*}{$\begin{array}{l}\text { Year brand } \\
\text { started }\end{array}$} & \multicolumn{2}{|c|}{ Competitive strategy } & \multicolumn{2}{|c|}{$\begin{array}{l}\text { Average market } \\
\text { share (\%) }\end{array}$} \\
\hline & & PQ-segment & Brand & & Market share goal & $\begin{array}{l}\text { Promotion } \\
\text { strategy }\end{array}$ & Gel \% & Foam \% \\
\hline \multirow[t]{5}{*}{$P \& G$} & \multirow{5}{*}{$\begin{array}{l}\text { Safety Razors } \\
\text { \& Blades }\end{array}$} & Premium & $\begin{array}{l}\text { Gillette } \\
\text { Fusion }\end{array}$ & 2006 & $\begin{array}{l}\text { To have the } \\
\text { highest market } \\
\text { share in the } \\
\text { premium gel } \\
\text { segment } \\
\text { competing on a } \\
\text { price at the lower } \\
\text { end }\end{array}$ & "Heavy" & 11.3 & \\
\hline & & \multirow[b]{2}{*}{ Mid-price } & Gillette Series & 1992 & \multirow{2}{*}{$\begin{array}{l}\text { To be a market } \\
\text { share leader or } \\
\text { hold a significant } \\
\text { market share } \\
\text { position }\end{array}$} & “Heavy” & 22.0 & \\
\hline & & & $\begin{array}{l}\text { Gillette } \\
\text { Foamy }\end{array}$ & 1953 & & "Moderate" & & 35.9 \\
\hline & & \multirow{2}{*}{ Economy } & \multirow{2}{*}{ Old Spice } & \multirow{2}{*}{ Acquired 1990} & & "Moderate" & & 7.6 \\
\hline & & & & & & "Heavy” & 0.08 & \\
\hline $\begin{array}{l}\text { S.C. } \\
\text { Johnson }\end{array}$ & $\begin{array}{l}\text { Household } \\
\text { Chemicals }\end{array}$ & Mid-price & Edge & $\begin{array}{l}\text { 1970: First } \\
\text { shaving gel for } \\
\text { men }\end{array}$ & $\begin{array}{l}\text { To be the market } \\
\text { share leader in the } \\
\text { gel segment }\end{array}$ & “Heavy” & 36.9 & \\
\hline \multirow[t]{2}{*}{$J \& J$} & Skin Care & $\begin{array}{l}\text { Super- } \\
\text { premium }\end{array}$ & $\begin{array}{l}\text { Neutrogena } \\
\text { Razor } \\
\text { Defense } \\
\end{array}$ & Acquired 1994 & \multirow[t]{2}{*}{$\begin{array}{l}\text { To focus on the } \\
\text { upper-price gel } \\
\text { segments }\end{array}$} & \multirow[t]{2}{*}{ "Light" } & 1.5 & \\
\hline & Dermatology & Premium & Aveeno & Acquired 1999 & & & 6.9 & \\
\hline $\begin{array}{l}\text { Beiersdorf } \\
\text { A.G. }\end{array}$ & Skin care & Mid-price & Nivea & $1930 \mathrm{~s}$ & $\begin{array}{l}\text { To compete at the } \\
\text { upper-end of the } \\
\text { mid-price segment }\end{array}$ & "Moderate & 5.7 & \\
\hline \multirow[t]{2}{*}{ Perio } & \multirow[t]{2}{*}{$\begin{array}{l}\text { Men's shaving } \\
\text { cream }\end{array}$} & \multirow[t]{2}{*}{ Economy } & \multirow[t]{2}{*}{ Barbasol } & $\begin{array}{l}\text { 1952: First } \\
\text { foam shaving } \\
\text { cream (men) }\end{array}$ & $\begin{array}{l}\text { To be the market } \\
\text { share leader in the } \\
\text { foam segment }\end{array}$ & "Moderate" & & 45.1 \\
\hline & & & & & & "Heavy” & 0.8 & \\
\hline \multirow{3}{*}{$\begin{array}{l}\text { Private-label } \\
\text { group }\end{array}$} & \multirow{3}{*}{$\begin{array}{l}\text { Retail store } \\
\text { channels }\end{array}$} & Economy & \multirow{3}{*}{ Store brands } & & & "Moderate" & 6.3 & \\
\hline & & Mid-price & & & & “Heavy” (2008) & & 1.6 \\
\hline & & Economy & & & & “Light” (2008) & & 0.2 \\
\hline
\end{tabular}


In the mid-price segment, $\mathrm{P} \& \mathrm{G}$ brands hold the second highest market share: Gillette Series in gel and Gillette Foamy in the foam segment. Although, Gillette Foamy trails Barbasol in market share this seems to have been by design because of which $P \& G$ appears to have chosen higher profitability over higher market share. In the premium gel segment Gillette Fusion has emerged as the market share leader within that segment in a very short span of time. Like the market share leader Edge, all the Gillette gel brands-including Fusion-are supported by a strategy of "heavy" promotion.

It appears that $\mathrm{P} \& \mathrm{G}$ has withdrawn Gillette Mach3 gel from the market. Two reasons seem to account for this. One is that the brand was able to generate an average market share of only $4.3 \%$ (see Table 9): a level that may be considered too low for a mid-price brand carrying the famous Gillette name. Second, P\&G had positioned Gillette Mach3 at the upper-end of the mid-price segment. So, Mach3 not only provided competition for its nearest rival Nivea, but may also have taken away some sales from P\&G's own brands: the Fusion line-positioned not too far above Mach3 at the lower-end of the premium segment-as well as the mid-price Series line.

As pointed out before, the prime mover of the Shaving industry-a multi-technology, multi-product business - is safety razor and blade technology. Yet, $P \& G$ is the only enterprise in this study that not only has this know-how, but is also the most innovative and by far the largest undertaking in this field with about 70\% of the global market share ${ }^{21}$. This offers P\&G several advantages:

- The Gillette brand has had a long history of bringing to market innovative razors and blades after every few years. So, this has allowed Gillette to leverage its successful brands, and pursue a line-extension strategy by introducing men's shaving gel—and other men's shaving products—carrying the same names borne by its highly successful safety razor and blades lines: Mach3 and Fusion.

- This line-extension strategy makes it possible for P\&G to employ joint advertising that benefits multiple products. For example, in 2007 it spent \$2.9 million on joint advertising under the Gillette Fusion brand that covered multiple products for men (see Table 7).

- The constant stream of innovations and improvements by the Gillette division frequently provides P\&G with a platform to engage in promotional campaigns to generate more sales ${ }^{22}$.

- P\&G has another major advantage in the promotional arena. Thanks to its extraordinarily broad and successful product line in the consumer market, every month it is able to distribute - through the local newspapers - "P\&G brand Saver": a package of discount coupons that are solely for P\&G brands.

At this stage we need to offer some comments on two brands. One is Old Spice which found itself placed in the economy segment for the gel and foam markets for both 2008 and 2007 (see Tables 1-4). Second is Noxzema gel which is a part of the economy segment for both years (see Tables 1-2).

P\&G bought the Old Spice brand in 1990 from Shulton Company ${ }^{23}$. However, in 2001 P\&G licensed the rights to the brand to Universal Group, a manufacturer and marketer of personal grooming products ${ }^{24}$. Even so it is important to point out that Old Spice does appear as a P\&G brand on its website. P\&G acquired Noxzema from Noxell Corp. in 1989, but then sold it to Alberto Culver in 2008, which, in turn, has licensed the rights to

\footnotetext{
${ }^{21}$ http://www.pg.com/en_US/investors/financial_reporting/annual_reports.shtml (2009 report, Retrieved on June 10, 2011).

22 The Gillette Fusion razor offers the latest example; see http://www.pg.com/en_US/brands/beauty_grooming/fusion.shtml (Retrieved on June 10, 2011).

${ }^{23}$ http://www.cr8on.com/shulton.html (Retrieved on June 10, 2011).

${ }^{24}$ http://www.universalgrp.com/ourcompany.html [We could not access this website as of Dec. 24, 2011].
} 
it to Universal Group ${ }^{25}$.

We have noted earlier that $P \& G$ does not normally compete in the economy segment. However, considering the U.S. shaving cream brands P\&G currently competes in the only exception is Old Spice. So, our inference is that $\mathrm{P} \& \mathrm{G}$ is keeping the home-grown Gillette brands away from the economy segment; yet, it is willing to compete in the economy segment with secondary brands like Old Spice which is manufactured and marketed by a third party under license from $P \& G^{26}$.

Gillette's focus on the "Deep Middle" in the gel segment. In order to understand the competitive strategy of $P \& G$, let us divide the price range of the gel segment into three levels. The top level can be visualized as the "shallow upper": a "high-price low-market share" space that includes the super-premium and the upper-premium segments: an arena that J\&J has chosen to concentrate in. The lowest level can be called the "shallow-lower": a "low-price low-market share" neighborhood a major occupier of which is the private-label group.

The middle level can be described as the "deep-middle" in which the competitors seek relatively high market share in both the lower-premium and the mid-price segments-uniformly supported by "heavy" promotion. It is this domain that P\&G's Gillette division has embraced.

As we have indicated before, increasing economic inequality in America since 1973 has sharply expanded the premium and the super-premium segments of the consumer market. Traditionally, Gillette had been competing in the mid-price segment. So, when P\&G launched the Gillette Fusion line in 2006 it introduced Gillette Fusion as a premium brand ${ }^{27}$.

In the men's shaving gel market Gillette Fusion's major rival is Aveeno which J\&J has positioned at the upper end of the premium segment. So, $P \& G$ has chosen a strategy of a premium price significantly lower than that of Aveeno. One of the core strengths of $P \& G$ is the expertise and infrastructure for advertising and product promotion through the mass-market retail channels. Thus, P\&G combined Gillette Fusion's price at the lower end of the premium segment with a strategy of "heavy" promotion, supported by strong advertising from time to time.

This strategy seems to have proved highly successful. It catapulted Gillette Fusion into the market-share leadership position within the premium segment soon after its introduction in 2006. Its market share (units) was 11.5\% and 11.1\%, respectively, for 2008 and 2007, compared to Aveeno's 6.7\% and 7.1\% (see Tables 1 and 2).

\section{S.C. Johnson}

S.C. Johnson has long been in the chemical industry specializing in household chemicals (see Tables 11-12). As mentioned earlier, the firm entered the personal care market in 1970 by introducing Edge - the first shaving gel for men. As mentioned before, the company discovered that gel was a better skin lubricant than the then-popular foam shaving cream.

Edge has been the leading brand in men's shaving gel market with an average market share of $36.9 \%$ for 2008 and 2007, far ahead of its nearest rival, Gillette Series which had a comparable figure of 22\% (see Table 9). As a first-mover, Edge has been able to accomplish this feat by competing in the mid-price segment and pursuing a generally aggressive strategy of promotion and advertising, based on the data for 2008 and 2007.

However, in 2009 S.C. Johnson sold its shaving cream business to Energizer Holdings - the owner of Schick razors and blades—-because this business provided a better fit for the latter.

\footnotetext{
25 http://www.universalgrp.com/ourcompany.html [We could not access this website as of Dec. 24, 2011].

${ }^{26}$ Although Gillette was technically an acquisition for P\&G, yet the brand had been a power house in the shaving business for a long time. So, it seems appropriate to regard long-standing Gillette brands as if they were organically grown for P\&G as well.

27 http://www.pg.com/en_US/investors/financial_reporting/annual_reports.shtml (2009 report, Retrieved on June 10, 2011).
} 
Edge offers too much variety? Laura Ries (2008) complains that "the number of Edge varieties is mind-boggling". She says Edge now comes in "8 flavors: Sensitive skin, extra moisturizing, extra protection, normal skin, tough beards, clean, ultra-sensitive and soothing aloe”. She asks the question: How many flavor varieties a brand should have? Then she answers the question herself by suggesting that the number three is just about right: "normal, ultra-sensitive skin, and tough beards".

She says S.C. Johnson \& Son is wrong in emphasizing "ADVANCED” and "REFRESH YOUR SHAVE," neither "of which is very compelling or something they own". Even though S.C. Johnson invented the gel shaving cream, yet the word "gel" appears rather small on the can. She points out that brands should emphasize their own strong position in their advertising and packaging. She therefore suggests that the word Gel should appear "large and bold on the can", because that is why customers buy Edge gel in the first place.

Perhaps the most critical comment offered by Laura Ries is that S.C. Johnson has failed to bolster its most important asset: that Edge is the leading brand in the men's shaving gel market.

\section{Johnson \& Johnson (J\& J)}

J\&J's basic know-how comes from the pharmaceutical industry (see Table 11). J\&J acquired Neutrogena in 1994. Neutrogena was a niche player in the premium-priced skin and hair care products. Its leading product, the "clear, clean-smelling" glycerin soap bar established it as a pioneer in the skin care field ${ }^{28}$.

J\&J bought Aveeno in 1999 for several reasons: (1) its unique use of natural ingredients; (2) the therapeutic benefit of its products to treat skin conditions (such as eczema, psoriasis, etc.); and (3) a long-standing relationship with dermatologists and pediatricians. ${ }^{29}$

Thus, the primary source of expertise for J\&J's entry in the shaving cream market has come from skin care and dermatology: areas that lend themselves very well to an image of premium-priced products.

As mentioned earlier, both brands belong to the "light" promotion group. It means that J\&J wants to protect the "high-price" image of its brands by not relying too much on discounting.

\section{Beiersdorf A.G.}

Beiersdorf A.G. is a German company that produces products for skin care, wound dressing, and sticking tapes. ${ }^{30}$ Thus, the entry of Nivea in the men's shaving cream gel market owes its origin to Beiersdorf's skin care pedigree.

So, Beiersdorf seems to have used its reputation in the skin care business to position Nivea gel around the top of the mid-price segment (see Table 9) as a cheaper alternative to the premium-priced Aveeno gel.

\section{Perio}

As we have observed earlier, Barbasol was not only the first successful brushless shaving cream, but also the first to change Barbasol's formulation in the 1950s from a thick cream in a tube to fluffy foam in an aerosol can.

From 1962 to 2001 Barbasol was owned by the pharmaceutical giant, Pfizer. In 2001, the current owner, Perio—a privately-held company_acquired Barbasol from Pfizer.

As previously discussed, Barbasol virtually dominates the foam shaving cream segment with an average market share in units of $45.1 \%$ (see Table 10). However, it has achieved this distinction by pursuing a low-price

\footnotetext{
${ }^{28}$ http://www.fundinguniverse.com/company-histories/Neutrogena-Corporation-Company-History.html (Retrieved on June 10, 2011).

${ }^{29} \mathrm{http}: / /$ www.aveenoprofessional.com/about-aveeno (Retrieved on June 10, 2011).

${ }^{30}$ http://www.fundinguniverse.com/company-histories/Beiersdorf-AG-Company-History.html (Retrieved on June 10, 2011).
} 
strategy with a price one-third lower than that of Gillette Foamy, its nearest competitor which had an average market share of $35.9 \%$. In contrast with Barbasol, Gillette Foamy is competing in the mid-price segment at an average price that was a whopping $51 \%$ higher, and yet has been able to capture a market share that is lower in units but higher in dollars.

Thus, it is reasonable to suggest that although Barbasol has won the market share war, it has been able to achieve this feat by following a strategy that in the long run may not perhaps score well on the profitability front. On the other hand, given that Barbasol has been able to capture very close to half the market share of the foam segment, it is conceivable that such a strategy may after all produce an adequate rate of return on investment in the long run.

Nevertheless, one major drawback of a low-price strategy is that it can saddle a brand with a "discount" image implying a lower perceived quality even though that may not necessarily be true in reality (Datta, 2010a). This may be one reason Barbasol has not been able to leverage its success in the foam market onto its gel business ${ }^{31}$.

Interestingly, Barbasol was able to increase its market share significantly from $42.7 \%$ in 2007 to $47.6 \%$ in 2008 , with a unit price that was $9 \%$ higher in 2008 , compared to $5 \%$ for the foam segment as a whole (see Tables 3-4). A major increase in advertising from $1 \%$ of sales to $8.4 \%$ seems to have played an important role in bringing this about.

\section{The Private-Label Group}

This is a group that consists of store brands of discount retail stores, food stores, and drug stores. Since it has to fight against major national and international brands, this group has chosen to compete in the economy gel segment. But, unlike national economy brands (e.g., Old Spice), it is relying only on a "moderate" promotional push. Yet, as a group, it has the highest market share in the economy segment with an average market share of $6.4 \%$ (see Table 9).

It is clear that this group has a relatively small presence in the foam market (see Table 10). Perhaps Barbasol's dominance of the economy segment seems to be the main reason behind this stance.

\section{Conclusion}

Contrary to Porter's idea, the best path for seeking market share leadership is not to pursue a low-price cost leadership strategy, but rather to cater to the middle class-that constitutes about $40 \%$ of U. S. households (Datta, 2011) — by competing in the mid-price segment (Datta, 2010a, 2010b). It is the same customer group that $P \& G$ has successfully served in the past (Lafley \& Charan, 2008, p. 12).

But, to become a market share leader a business must also offer-relative to the nearest competition—a higher customer-perceived quality at a somewhat higher price. This is necessary for two reasons: (1) to maintain an image of quality; and (2) to make sure the strategy is profitable and sustainable.

First, we explored the history and technology of the U.S. Men's Shaving Cream market. Then we performed cluster analysis for 2008 and 2007 using a single variable-average net unit price-to test the hypothesis that the top-selling brand (in terms of unit sales) is very likely to be in the mid-price segment with a price tag that is higher than that of the nearest competition. The results for the gel segment-by far the most important—-turned out to be positive. Although, technically, the outcome for the foam segment was negative,

${ }^{31}$ It is worth noting that for 2008 and 2007 Barbasol has only a miniscule average market share (in units) of $0.8 \%$ in the gel market (see Table 9) even while continuing to compete in the economy segment. 
the result does not necessarily falsify the above hypothesis.

A remarkable finding is that, for both the gel and foam segments, we found the rank order correlation of brand unit price between 2007 and 2008 as very significant. This means that managers regard the price of a brand as a strategic rather than a tactical variable.

Finally, we identified six strategic groups in the industry, and have tried to articulate the competitive strategy each group has adopted in the men’s shaving cream market.

\section{References}

Berlow, L. (1993). How products are made, 1. Retrieved June 10, 2011, from http://findarticles.com/p/articles/mi_gx5205/is_1993/ai_n19124452/

Burke, M. (2009). S.C. Johnson sells shaving-prep brands to Energizer Holdings. Retrieved June 10, 2011, from http://www.journaltimes.com/news/local/article_3bd9a38c-02e6-5f86-8b42-3763550855dc.html

Buzzell, R. D. (2004). The PIMS program of strategy research: A retrospective appraisal. Journal of Business Research, 57(5), 478-83.

Buzzell, R. D., \& Gale, B. T. (1987). The PIMS principles: Linking strategy to performance. New York: Free Press.

Cole, D. J., Browning, E., \& Schroeder, F. (2003). Encyclopedia of everyday inventions. Westport, CT: Greenwood Press.

Datta, Y. (1996). Market segmentation: An integrated framework. Long Range Planning, 29(6), 797-811.

Datta, Y. (2010a). A critique of Porter's cost leadership and differentiation strategies. Chinese Business Review, 9(4), 37-51.

Datta, Y. (2010b). Strategic group theory: A customer-oriented view. Chinese Business Review, 9(7), 11-26, 36.

Datta, Y. (2012). Rising economic inequality and class divisions in America: A socio-economic class lifestyle profile. Oxford Journal, February, ISSN 1551-4498 (forthcoming).

Gale, B. T. (1992). Quality comes first when hatching power brands. Planning Review, July-August, pp. 4-9.

Hamel, G., \& Prahalad, C. K. (1994). Competing for the future: Breakthrough strategies for seizing control of your industry and creating the markets of tomorrow. Boston: Harvard Business School Press.

Howe, P. J. (2005). For the past half century, Cutting Edge' has meant more at Gillette than a sharp blade. The Boston Globe, Jan. 30, D1.

Ketchen, Jr., D. J., \& Shook, C. L. (1996). The application of cluster analysis in strategic management research: An analysis and critique. Strategic Management Journal, 17, 441-58.

Lafley, A. G., \& Charan, R. (2008). The game changer: How you can drive revenue and profit growth with innovation. New York: Crown Business.

Larson, M., \& Sundberg, J. L. (2006). Sunday drives: Nostalgic reminiscing with the best of Burma-Shave. New York: iUniverse, Inc..

Mintzberg, H. (1988). Generic strategies: Toward a comprehensive framework. In R. Lamb, \& P. Shrivastava (Eds.), Advances in strategic management (Vol. 5). Greenwich, CT: JAI Press.

The New York Times. (1989). Company news: Gillette is guilty in patent case. Aug. 2.

Oxenfeldt, A. R. (1960). Multi-stage approach to pricing. Harvard Business Review, 38(4), 125-133.

Pinfold, W. C. (1999). A closer shave: Man's daily search for perfection. New York: Artisan, a division of Workman Publishing Co..

Porter, M. E. (1980). Competitive strategy. New York: Free Press.

Porter, M. E. (1985). Competitive advantage. New York: Free Press.

Ries, L. (2006). Ries's pieces: Over the edge. Retrieved June 10, 2011, from http://ries.typepad.com/ries_blog/2006/08/over_the_edge.html

Rosen, M. J. (2004). Surfactants and interfacial phenomena (3rd ed.). Hoboken, N.J.: John Wiley \& Sons.

Rowsome, F. Jr. (1965)._The verse by the side of the road: The story of Burma-Shave signs and jingles. Battleboro, VT: Stephen Green Press.

Shapiro, B. P. (1968). The psychology of pricing. Harvard Business Review, 46 (4): 14-25, 160.

Sloan, P. (1988). Edge loses its edge. Advertising age, 59(5), 3.

Sviokla, J., \& Paoni, A. J. (2005). Every product’s a platform. Harvard Business Review, 83(10).

Tickner, D. (2009). My Colgate shave cream, Gone! Retrieved June 10, 2011, from http://www.brandlandusa.com/2009/02/05/my-colgate-shave-cream-gone/

Toedt, J., Koza, D., \& Cleef-Toedt, K.V. (2005). Chemical composition of everyday products. Westport, CT: Greenwood Press.

Woodward, H. (1939). Pocket guide. Nation, 148(16), 430-431. 